\title{
Implementasi Six Sigma untuk Perbaikan Kualitas Produk Kiwi Paste Berdasarkan Keluhan Pelanggan
}

\author{
Nelfiyanti Nelfiyanti*, Annisa Mulia Rani, Achmad Fauzi \\ Program Studi Teknik Industri, Fakultas Teknik, Universitas muhammadiyah Jakarta, Jl. Cempaka Putih Tengah III No.24, \\ RT.11/RW.5, Jakarta Pusat, Jakarta 10510 Indonesia
}

\section{ARTICLE INFORMATION}

Article history:

Received: April 25, 2018

Revised: July 23, 2018

Accepted: July 27, 2018

Kata Kunci:

DMAIC

DPMO

Keluhan Pelanggan

Level Sigma

\section{A B S T R A K}

PT. LF Beauty Manufacturing Indonesia adalah sebuah kelompok perusahaan Li \& Fung berpusat di Hongkong yang bergerak dalam bidang jasa manufaktur. Perusahaan memiliki 4 pelanggan tetap, yaitu: PT JHHP, PT.Diversey, PT.Topindo dan PT.Wavin. Selama tahun 2015 perusahaan mendapatkan 12 keluhan cacat yang mana 8 keluhan berasal dari PT. JHHP. Penelitian ini bertujuan untuk mengetahui penyebab keluhan cacat PT JHHP, memberi perbaikan untuk masalah yang ada sehingga tidak terjadi di masa mendatang dan sebagai alat ukur produktivitas perusahaan untuk meningkatkan kualitas produksi. Metode penelitian ini menggunakan Six Sigma dengan tahapan DMAIC (Define Measure, Analyze, Improvement, Control). Objek penelitian adalah data produksi bulan Agustus 2015 sesuai dengan data keluhan pelanggan. Hasil analisa dari keluhan pelanggan JHPP diperoleh cacat terbesar produk kiwi paste yang sesuai dengan diagram adalah finish good bocor. Faktor - faktor yang mempengaruhi keluhan cacat finish good bocor produk kiwi paste adalah operator sering melakukan adjusment angin mesin autocapper, belum tersedianya alat termometer ruang pada area warehouse dan area dry produksi, belum tersedianya alat ukur tekanan angin yang dipakai untuk mengetahui jumlah bar yang dipakai dalam proses asemble dan temperatur ruang area penyimpanan melebihi dari standar dari yang ditetapkan. Nilai defect mengalami penurunan, sebelum implementasi 3.497 DPMO dengan level sigma 4,20 menjadi 568 DPMO dengan level sigma 4,75 .

\section{A B S T R A C T}

PT. LF Beauty Manufacturing Indonesia is a Hong Kong-based Li \& Fung group of companies engaged in manufacturing services. The Company has 4 regular customers, namely: PT JHHP, PT.Diversey, PT.Topindo and PT.Wavin. During 2015 the company got 12 defect complaints which 8 complaints came from PT. JHHP. This study aims to determine the cause of disability complaints of PT JHHP, provide improvements to existing problems so that it does not occur in the future and as a measure of company productivity to improve production quality. This research method uses Six Sigma with DMAIC stages (Define Measure, Analyze, Improvement, Control). The object of research is the production data of August 2015 in accordance with customer complaints data. The result of analysis of JHPP customer's complaint obtained the biggest defect of kiwi paste product according to the diagram is finish good leak. Factors affecting the defect complaints of the finish good leaked kiwi paste product is the operator often do autocapper engine wind adjusment, unavailability of space thermometer tool in the warehouse area and dry production area, unavailability of wind pressure gauge used to determine the number of bars used in the asemble process and the temperature of the storage area space exceed the standard set. Defect value decreased, before implementation of 3.497 DPMO with sigma level 4.20 to 568 DPMO with 4.75 sigma level. 


\section{PENDAHULUAN}

PT. LF Beauty Manufacturing Indonesia adalah sebuah kelompok perusahaan Li \& Fung berpusat di Hongkong yang bergerak dalam bidang jasa manufaktur. PT. LF Beauty Manufacturing Indonesia hanya memproduksi produk perusahaan pelanggan (customer) sesuai kebutuhan perusahaan pelanggan itu sendiri. PT LF Beauty Manufacturing Indonesia memiliki dua pabrik produksi yaitu area Personal Care dan area Home Care.

Penelitian ini dilakukan pada area Home Care. Pada area ini perusahaan sudah memiliki 4 pelanggan tetap, yaitu: PT JHHP, PT.Diversey, PT.Topindo, dan PT.Wavin. Untuk jenis produksi yang dihasilkan dari setiap costumer berbedabeda, PT JHHP memproduksi produk kiwi paste dan kiwi liquid, PT Diversey memproduksi produk sabun home care size 5 ltr, 20 ltr, 200 Itr dan 1 ton, PT. Topindo memproduksi water coolant size $500 \mathrm{ml}, 1$ liter dan 4 liter, gear matic $100 \mathrm{ml}$ dan $120 \mathrm{ml}$, dan shock absorber size $150 \mathrm{ml}$, dan PT Wavin memproduksi wavin glue size $60 \mathrm{gr}$ dan 400gr.

Permasalahan terjadi pada Departemen Quality, yaitu banyaknya keluhan (complaint) atas produk yang dihasilkan perusahaan. Tercatat pada tahun 2015, perusahaan sudah menerima keluhan produk sebanyak 12 keluhan. Berdasarkan data costumer complaint di atas, complaint terbanyak diberikan oleh PT JHHP sebanyak 8 keluhan, setelah itu disusul oleh PT. Diversey, dan PT Topindo masingg-masing dua keluhan. Berdasarkan jumlah keluhan maka penelitian ini berfokus untuk menyelesaikan keluhan PT JHHP.

Salah satu metode yang digunakan untuk meningkatkan kualitas produk adalah metode Six Sigma. Six Sigma adalah metode terstruktur yang digunakan untuk mengurangi variasi dan meningkatkan proses [1]. Tujuan Six Sigma adalah untuk meningkatkan kinerja proses dan mencapai tingkat kualitas yang tinggi dengan menyelidiki dan menghilangkan akar penyebab cacat dan meminimalkan proses dan variabilitas produk [2].

Six Sigma telah berhasil digunakan dan diimplementasikan dalam berbagai konteks dan proses yang berbeda oleh banyak organisasi seperti dalam bidang jasa [3], [4], manufaktur [5], [6] dan bidang-bidang lainnya. Six Sigma dalam aplikasinya mempunyai lima fase yang disebut siklus DMAIC (Define, Measure, Analyze,
Improve, dan Control) [7] yang dipakai untuk memandu implementasi Six Sigma dalam mencapai tujuan perusahaan. Model DMAIC mengacu pada lima tahapan yang saling berhubungan yang secara sistematis membantu organisasi untuk memecahkan masalah dan memperbaiki prosesnya [8]. Tahapan T DMAIC ini bertujuan mengidentifikasi permasalahan yang terjadi, menganalisa penyebab masalah dan mencari upaya perbaikan untuk menapatkan penyelesaian terbaik.

Penggunaan metode Six Sigma secara langsung meningkatkan layanan pelanggan dan produktivitas di perusahaan otomotif [9]. Faktor kepemimpinan dan fokus pada kebutuhan pelanggan merupakan kunci sukses dalam implementasi Six Sigma. [10]. Six Sigma dalam organisasi dapat mengarah pada profitabilitas, perubahan budaya, dan mendapatkan loyalitas pelanggan.

Six Sigma secara berkelanjutan akan membentuk budaya dengan sikap perbaikan terus menerus untuk meningkatkan kualitas produk dalam rangka meningkatkan kepuasan pelanggan, mengurangi biaya operasional, dan meningkatkan pangsa pasar [11]. Menciptakan dan mempertahankan loyalitas pelanggan adalah tantangan utama bagi organisasi karena manajemen menyadari fakta, bahwa diperlukan lima hingga tujuh kali lebih banyak waktu dan biaya untuk menggantikan, mempertahankan pelanggan [12].

Penelitian bertujuan untuk meminimalkan keluhan pelanggan PT JHPP melalui implementasi Six Sigma yang diharapkan dapat mengatasi keluhan pelanggan yang sama dikemudian hari dan sebagai alat ukur produktivitas perusahaan untuk meningkatkan kualitas produksinya.

\section{METODE PENELITIAN}

Penelitian ini menggunakan data komplain yang diterima perusahaan dari 4 pelanggan tetap, yaitu: PT JHHP, PT.Diversey, PT.Topindo, dan PT.Wavin pada tahun 2015. Dari keempat pelanggan akan dipilih pelanggan yang mengalami keluhan paling banyak, dalam hal ini adalah PT.JHHP. Data keluhan pelanggan akan dibandingkan dengan hasil produksi dan cacat pada tanggal produk Kiwi Paste di produksi. Data tersebut sebagai dasar untuk menganalisa permasalahan yang terjadi menggunakan metode Six Sigma untuk mendapatkan solusi terbaik untuk mengatasi permasalahan tersebut. 


\section{Define}

Define adalah langkah awal dalam tahapan Six Sigma yang berguna untuk menentukan permasalahan yang hendak diselesaikan. Pada tahapan ini akan dilakukan pemilihan proyek Six Sigma berdasarkan keluhan pelanggan. Dari keluhan yang diterima perusahaan pada tahapan ini fokus akan menyelesaikan keluhan pelanggan PT. JHPP mengenai produk yang cacat pada proses produksi Kiwi Paste berdasarkan Critical to Quality (CTQ). CTQ produksi Kiwi Paste terbagi menjadi isi finish good dalam satu karton kurang, finish good bocor, finish good kotor, dan finish good penyok. Dari CTQ yang ada dipilih jenis cacat yang terjadi menggunakan diagram pareto.

\section{Measure}

Measure adalah tahapan pengukuran tingkat kinerja yang ada, dengan tujuan untuk menganalisa berdasarkan target yang telah ditentukan [13], [14]. Langkah measure bertujuan untuk mendapatkan pengukuran kinerja dan kapabilitas proses yang digunakan untuk membandingkan kinerja suatu proses dengan spesifikasi yang telah ditetapkan [15]. Pada tahapan ini akan diukur nilai Sigma untuk mengetahui level perusahaan menurut Six Sigma dan mengetahui kondisi proses produk saat ini yang dapat digunakan sebagai acuan untuk pengambilan keputusan dalam menentukan langkah perbaikan selanjutnya.

$\mathrm{DPMO}=\frac{\text { Jumlah Cacat }}{\text { Jumlah Produksi } \times \text { CTQ }} \times 1.000 .000$

Tingkat Sigma $=\frac{\text { normsinv }(1000000-\text { DPMO })}{100000}+1,5$

\section{Analyze}

Analyze adalah tahapan pengidentifikasian masalah yang akan diselesaikan berdasarkan hasil dari tahapan measure. Pada tahapan ini menggunakan diagram fishbone untuk mengetahui faktor-faktor yang menyebabkan masalah tersebut.

\section{Improve}

Improve merupakan tahapan mengurangi penyebab terjadinya masalah yang terjadi. Pada tahapan ini akan dilakukan langkah-langkah perbaikan dengan tujuan meminimalkan permasalahan yang ada terjadi lagi. Tahap improve akan memberikan rekomendasi mengenai langkah-langkah yang perlu dilakukan untuk mengatasi masalah yang ada berdasarkan analisa masalah yang telah dilakukan pada tahapan sebelumnya.

\section{Control}

Tahapan control merupakan tahapan untuk mengukur keberhasilan perbaikan yang telah dilakukan. Pada langkah ini akan dibandingkan nilai sigma sebelum perbaikan dan sesudah perbaikan sebagai evaluasi program yang telah dilakukan telah sesuai dengan target yang telah ditentukan atau belum.

\section{HASIL DAN PEMBAHASAN}

Dalam pengendalian kualitas produksi Kiwi Paste berdasarkan metode Six Sigma. Tahapan Six Sigma dalam pemecahan masalah kualitas produk Kiwi Paste menggunakan tahapan DMAIC yang terdiri dari Define, Measure, Analyze, Improve dan Control.

\section{Define}

Define merupakan tahapan awal dalam mendefinisikan sebuah masalah, yaitu tahapan pendefinisian pemilihan program Six Sigma, pareto diagram, dan proses-proses kunci dalam program Six Sigma. Kriteria pemilihan program Six Sigma pada PT. LF Beauty Manufacturing Indonesia adalah menggunakan data history perusahaan dari tingkat performa proses produksi Kiwi Paste dengan pelanggan PT JHPP sebagai fokus penelitian.

Produk Kiwi Paste memiliki empat kategori defect complaint diantaranya adalah isi finish good dalam satu karton kurang, finish good bocor, finish good kotor, dan finish good penyok. Untuk itu pemilihan program kualitas akan dilanjutkan dengan menentukan empat kategori jenis defect complaint yang paling bermasalah dengan melihat persentase jumlah defect terbanyak yang terjadi diproses produksi.

Penentuan masalah didasarkan atas data keluhan pelanggan PT JHPP pada tahun 2015 sebanyak 8 kali keluhan dengan defect kemasan bocor dengan jumlah 3 keluhan, defect finish good kotor sebanyak 2 keluhan, defect finish good bocor sebanyak 2 keluhan, dan defect isi finish good kurang dalam satu karton sebanyak 1 complaint. Dari keempat jenis defect, defect finish good bocor yang menjadi prioritas dalam program Six Sigma ini karena defect tersebut adalah defect tertinggi dibanding defect lainnya 
Tabel 1. Data Keluhan Pelanggan PT. JHHP Tahun 2015

\begin{tabular}{|c|c|c|c|c|c|}
\hline No. & Jenis Keluhan & Produk & Tanggal Produksi & $\begin{array}{l}\text { Jumlah } \\
\text { Total } \\
\text { Temuan } \\
\text { Keluhan } \\
\text { (pcs) }\end{array}$ & $\begin{array}{l}\text { Jumlah } \\
\text { Unit } \\
\text { Produksi } \\
\text { Produk } \\
\text { (pcs) }\end{array}$ \\
\hline 1 & $\begin{array}{l}\text { Isi Finish Good dalam } \\
\text { Satu Karton Kurang }\end{array}$ & $\begin{array}{l}\text { Kiwi Shoe Polish } \\
\text { Brown } 17,5 \mathrm{ml}\end{array}$ & 30 Agustus 2016 & 3 & 12960 \\
\hline 2 & Finish Good Bocor & $\begin{array}{l}\text { Kiwi Paste Black } 100 \\
\text { ML/72 TH }\end{array}$ & 03 Agustus 2016 & 72 & 2448 \\
\hline 3 & Finish Good Bocor & $\begin{array}{l}\text { Kiwi Paste Black } 45 \\
\text { ML/72 TH }\end{array}$ & 28 Agustus 2016 & 49 & 5184 \\
\hline 4 & Finish Good Bocor & $\begin{array}{l}\text { Kiwi PGP Neutral } 50 \\
\text { ML/12DE VA/670231 }\end{array}$ & 03 Agustus 2016 & 191 & 4800 \\
\hline 5 & Finish Good Kotor & $\begin{array}{l}\text { Kiwi Paste Black } 100 \\
\text { ML/72 TH }\end{array}$ & 03 Agustus 2016 & 100 & 2448 \\
\hline 6 & Finish Good Kotor & $\begin{array}{l}\text { Kiwi PGP Brown } 50 \\
\text { ML/12DE VA/670229 }\end{array}$ & 07 Agustus 2016 & 103 & 4920 \\
\hline 7 & Finish Good Penyok & $\begin{array}{l}\text { Kiwi Paste Black } 100 \\
\text { ML/72 TH }\end{array}$ & 03 Agustus 2016 & 15 & 2440 \\
\hline \multirow[t]{2}{*}{8} & Finish Good Penyok & $\begin{array}{l}\text { Kiwi Paste Black } 45 \\
\text { ML/72 TH }\end{array}$ & 28 Agustus 2016 & 32 & 5184 \\
\hline & & & Total & 565 & 40392 \\
\hline
\end{tabular}

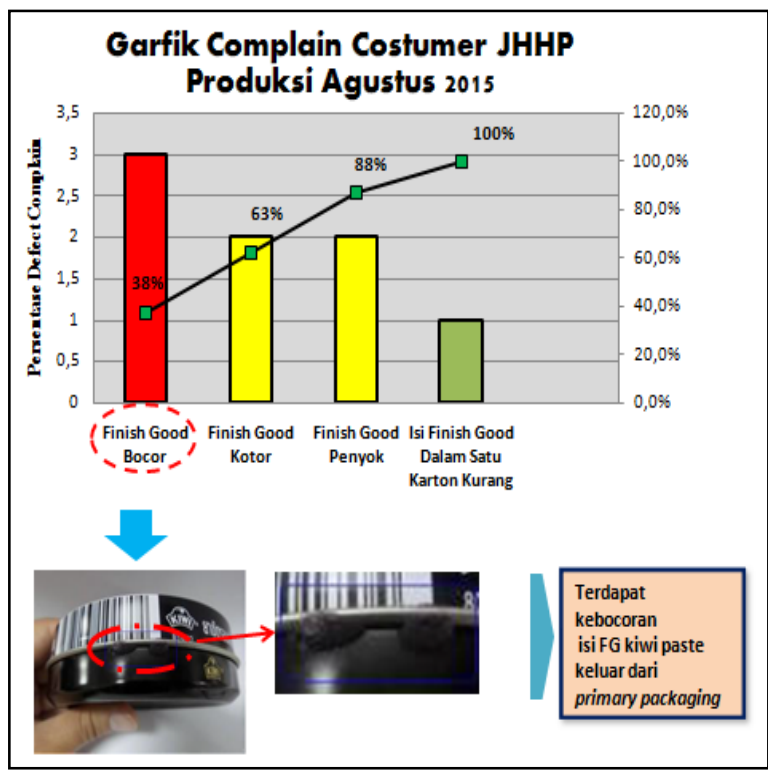

Gambar 1. Diagram Pareto Keluhan Pelanggan

$$
\text { PT. JHHP }
$$

\section{Measure}

Measure adalah langkah operasional kedua dalam program peningkatan kualitas Six Sigma. Untuk mengetahui kapabilitas proses produksi perlu dilakukan pengukuran Baseline kinerja atribut karakteristik pada tingkat output.

Perhitungan DPMO menggunakan data diskrit, yaitu data jumlah produksi pada bulan Agustus 2015. Data tersebut merupakan hasil produksi dari produk complaint Finish Good Bocor yang diberikan oleh costumer yang digunakan untuk pengukuran kemampuan proses (performance) Kiwi Paste melalui Sigma Quality Level.

Tabel 2. DPMO dan kapabilitas Sigma Kiwi Paste bulan Agustus 2015

\begin{tabular}{ccccc}
\hline $\begin{array}{c}\text { Total } \\
\text { Produksi }\end{array}$ & $\begin{array}{c}\text { Total } \\
\text { Cacat }\end{array}$ & CTQ & DPMO & $\begin{array}{c}\text { Nilai } \\
\text { Sigma }\end{array}$ \\
\hline 40392 & 565 & 4 & 3,497 & 4,20 \\
\hline
\end{tabular}

$\mathrm{DPMO}=\frac{565}{40392 \times 4} \times 1.000 .000$

DPMO $=3497$

Selanjutnya konversi DPMO menjadi kapabilitas Sigma dapat dilakukan dengan menyesuaikan dengan tabel konversi Six Sigma. Untuk nilai 
DPMO 3.497 ini, kapabilitas Sigmanya adalah 4,20 . Angka ini didapat dari hasil perhitungan sebagai berikut:

$\begin{aligned} \text { Sigma } & =\text { normsinv }((1.000 .000- \\ & \text { DPMO }) / 1.000 .000)+1,5 \\ = & \text { normsinv }((1.000 .000- \\ & 3.497) / 1.000 .000)+1,5 \\ = & 4,20\end{aligned}$

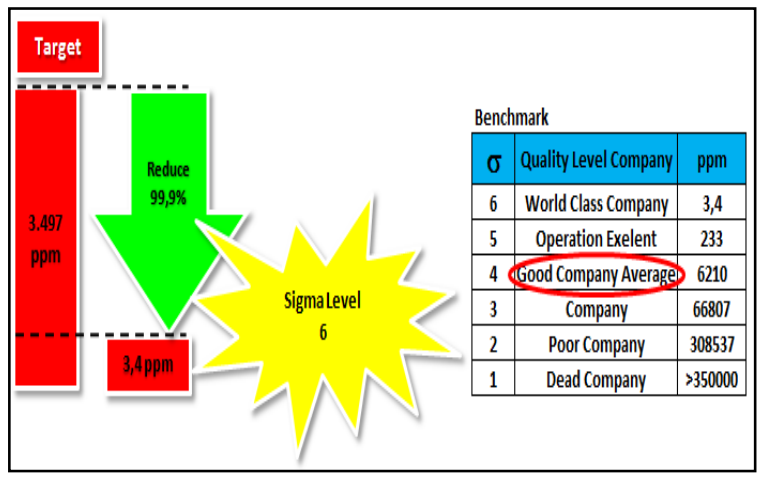

Gambar 2. Level Perusahaan berdasarkan Six Sigma

Pengukuran Sigma Quality Level bertujuan untuk mengetahui perbandingan kondisi proses produksi perusahaan dengan standar proses terbaik terbaik (world class) dan juga sebagai data terukur untuk menetapkan target perbaikan. Perbandingan ini sebagai dasar melakukan analisa perbaikan untuk meningkatkan Sigma Quality Level Perusahaan. Berdasarkan dapat diketahui bahwa kemampuan proses Kiwi Paste dengan defect kemasan bocor yang dicapai berdasarkan sigma quality level adalah menempati kualitas perusahaan dengan level good company average

Secara umum kinerja perusahaan sudah baik, akan tetapi perlu langkah-langkah perbaikan untuk mendapatkan posisi yang lebih baik lagi. Dengan melihat kemampuan perusahaan tersebut yang berada pada level good company average, maka target perbaikan yang akan dicapai adalah mengurangi tingkat cacat (jumlah market claim) sebesar 99,88 \% atau meningkatkan sigma quality level menjadi $6 \sigma$.

\section{Analyze}

Analisa faktor-faktor yang menjadi akar penyebab masalah Finish Good bocor pada item Kiwi Pasta dapat menggunakan fishbone diagram. Pembuatan fishbone diagram dilakukan dengan memasukkan semua faktor yang mungkin menjadi penyebab masalah dengan cara brainstorming dan diskusi. Hasil brainstorming adalah seperti yang tampak pada gambar 5. Faktor penyebab dalam fishbone diagram secara umum digolongkan atas faktor manusia (man), metode (method), mesin (machine), dan bahan baku (material).

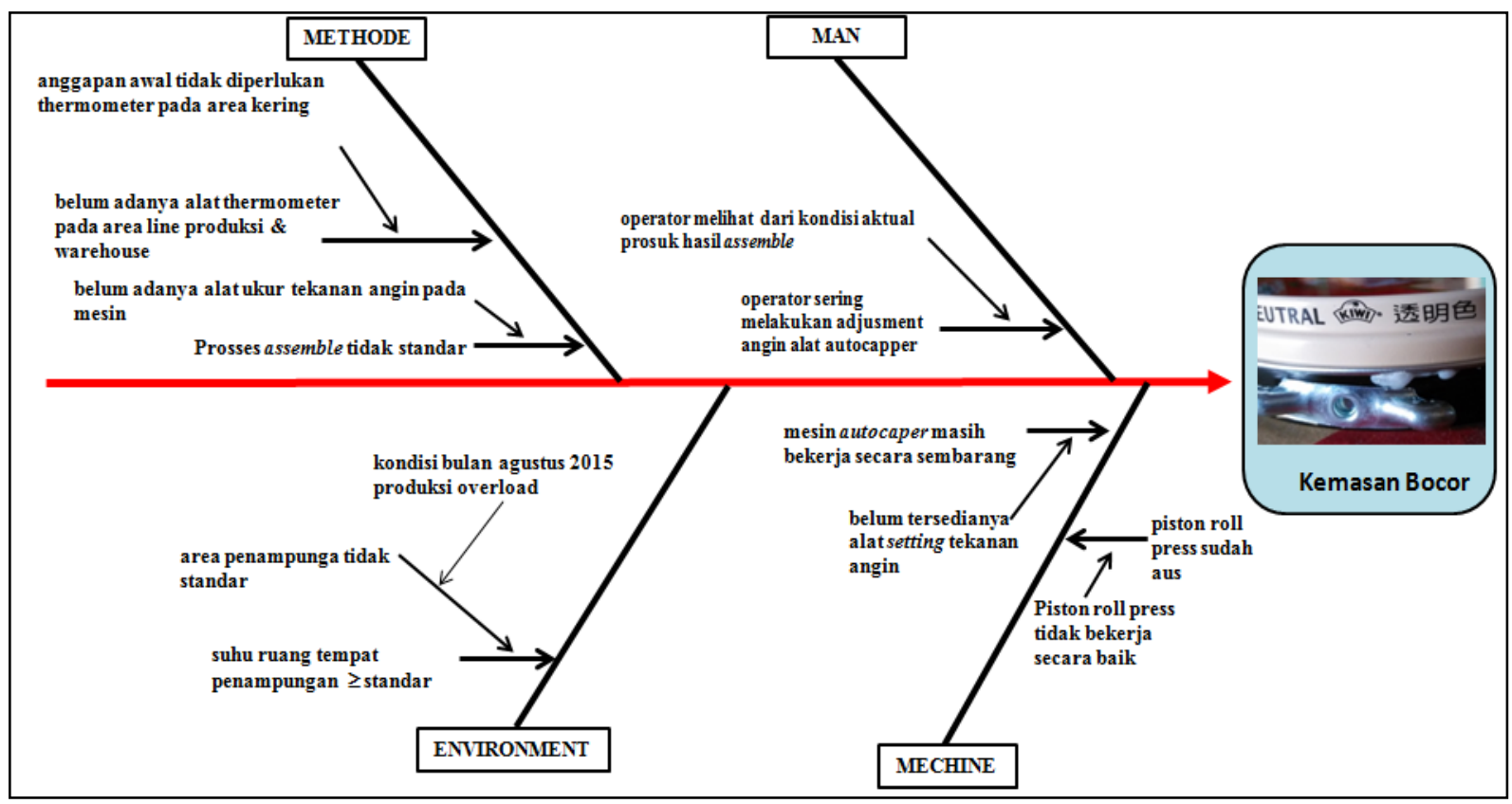

Gambar 4. Fishbone Finish Good Bocor Pada Kiwi Paste 
Dalam analisa diagram fishbone, faktor manusia sangat mempengaruhi terjadinya defect kemasan bocor pada saat proses assemble dengan menggunakan mesin auto capper. Mesin auto capper disini adalah jenis mesin peneumatic yang memanfaatkan tenaga angin sebagai motor mesin, dalam hal ini operator selalu melakukan adjustment angin dengan melihat dari hasil aktual proses assemble yang dihasilkan (Gambar 4). Pengetahuan setiap operator berbeda-beda sesuai dengan pengalaman masing-masing. Hal inilah yang menghasilkan proses assemble tidak sempurna.

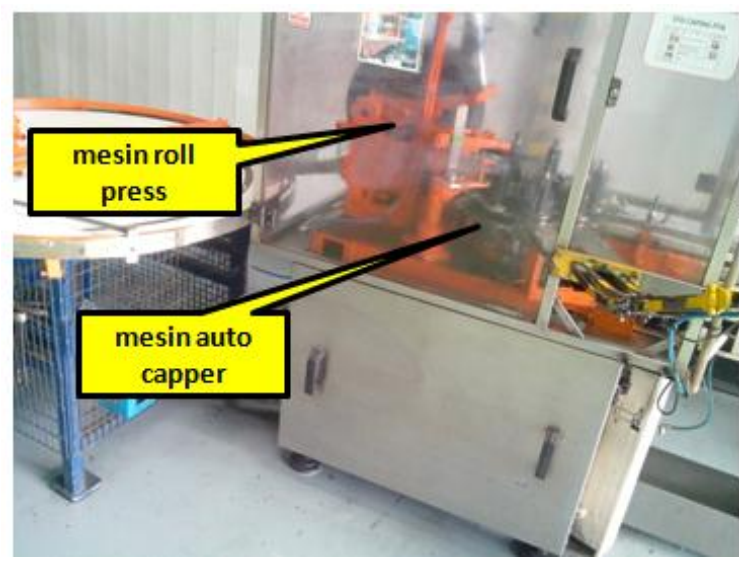

Gambar 4. Mesin Auto Capper

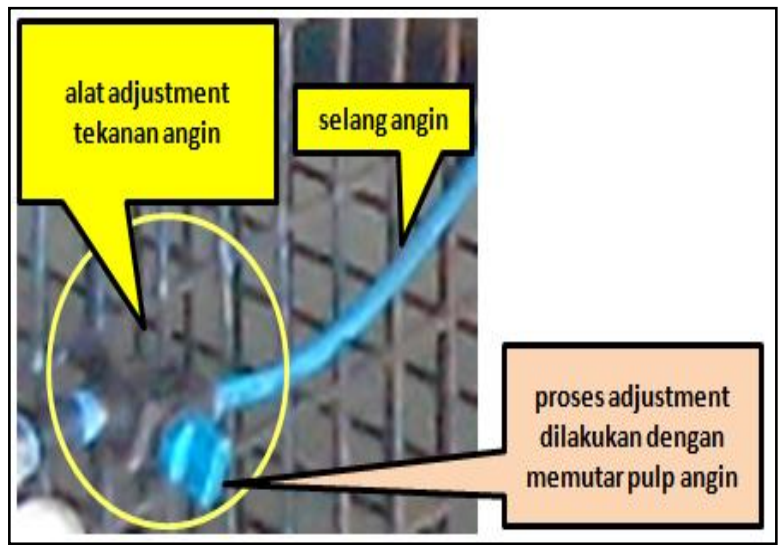

Gambar 5. Alat Adjustment Angin Auto Capper

Dalam analisa diagram fishbone, faktor metode disini terbagi menjadi dua, yaitu proses assemble tidak standar dan belum adanya alat thermometer ruang pada area line produksi dan warehouse. Dalam proses assemble tidak standar yang disebabkan karena belum tersedianya alat ukur tekanan angin pada mesin yang mengakibatkan operator tidak mengetahui berapa kepastian dari jumlah angin yang digunakan pada saat proses assemble (Gambar $5)$.
Dari faktor environment yaitu, temperature ruang area penyimpanan melebihi standar yang ditetapkan. Standar untuk penyimpanan produk finish good kiwi adalah pada temperatur kering yaitu antara $27{ }^{\circ} \mathrm{C}-30{ }^{\circ} \mathrm{C}$ dan dengan kelembapan normal, pada suhu penyimpanan di bulan Agustus berada di atas standar. Hal tersebut dikarenakan aktivitas produksi pada bulan Agustus 2015 mengalami over kapasitas sehingga FG yang belum sempat terkirim dan menunggu pengiriman ditempatkan pada area yang tidak sesuai.

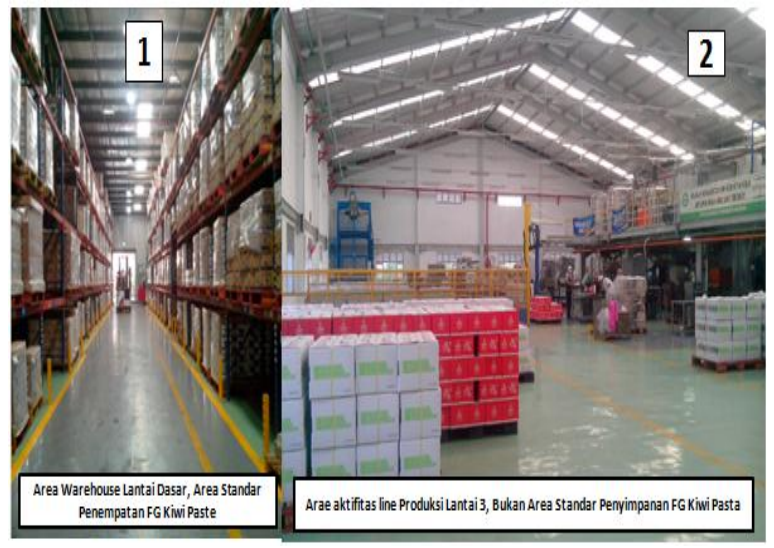

Gambar 6. Area Tempat Penyimpanan Produk Finish Good di Bulan Agustus 2015

Gambar 6 bagian 1 adalah area warehouse finish good yaitu area lokasi standar yang memang dikhususkan untuk area penyimpanan produk finish good, dengan posisi di lantai dasar dan tidak menerima panas matahari yang menyengat. Gambar nomer 6 bagian 2, adalah area line produksi PT.Topindo dengan produk water coolant dan area mixing PT. Diversey. Lokasi berada di area gedung lantai 3 dan area cukup panas, terlebih saat bulan Agustus sedang musim kemarau yang terik .

Pada kondisi bulan Agustus terjadi over PO yang sangat meningkat hingga mencapai 4.994 .220 pcs dengan angka standar target perusahaan adalah 2.900.000 pcs hingga 3.200.000 pcs. Pada kondisi itu, banyak produk finish good yang disimpan pada area gambar 6 poin 2 dikarenakan kapasitas dari gudang warehouse tidak dapat menampung seluruh jumlah kapasitas produksi. Pengiriman produk finish good ke costumer pun tidak berjalan seimbang dari permintaan produksi. Diantaranya adalah buffer stock, produk permintaan costumer yang telah disetujui oleh perusahaan dengan tujuan save cost dari biaya pembelian material dan biaya produksi berdasarkan dari permintaan konsumen tahun 2015. 


\section{Improve}

Pada tahapan improve, yang dilakukan adalah melakukan usulan perbaikan berdasarkan diagram fishbone yang telah diperoleh. Implementasi yang dilakukan pada mesin adalah dengan melakukan pemasangan alat ukur tekanan angin di unit mesin auto capper. Alat ukur ini digunakan untuk mengetahui berapa kondisi aktual angin, tekanan bar yang dipakai pada kerja mesin auto capper tersebut.

Setelah dilakukan instalasi alat set bar auto capper (gambar 7) lalu dilakukan proses validasi dari jumlah bar yang diperlukan untuk mesin auto capper. Proses yang dilakukan adalah

1. Dilakukan beberapa sample variasi dari jumlah tekanan bar yaitu : 2.2 bar, 3 bar, 4 bar, 5 bar , 6 bar.

2. Lalu dilakukan aging didalam oven pada temperature $38^{\circ} \mathrm{C}$ selama 16 jam

3. Dilihat dari jumlah finish good yang bocor

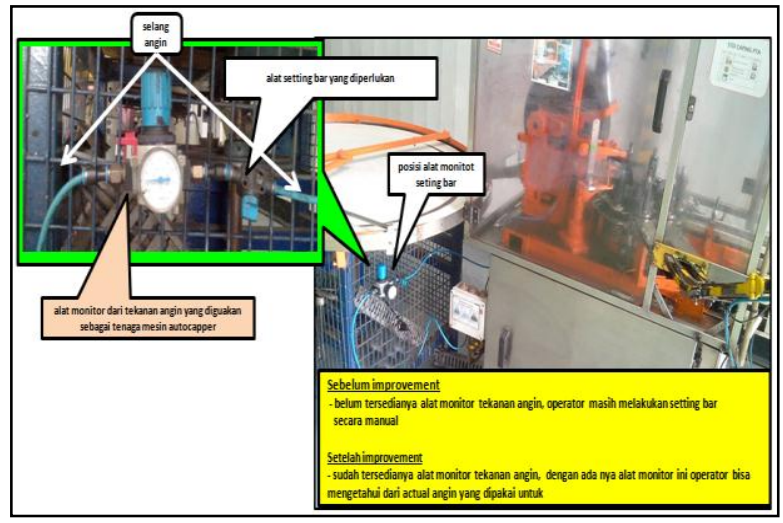

Gambar 7. Instalasi alat monitor tekanan angin bar auto capper

Berdasarkan data validasi yang dilakukan oleh Tim PCD dan Quality didapatkan hasil, pada percobaan tekanan bar 2,2 diperoleh hasil 3 dari 30 sample finish good bocor atau sebanyak $10 \%$ dari sampel bocor. Pada percobaan tekanan bar 3 diperoleh hasil 1 dari 30 sampel finish good bocor atau sebanyak $3 \%$ dari sampel bocor. Pada percobaan tekanan bar 4 diperoleh hasil 2 dari 30 sampel finish good bocor atau sebanyak $7 \%$ dari sample bocor. Pada percobaan tekanan bar 5 diperoleh hasil tidak ditemukan finish good bocor atau sebanyak $0 \%$ dari sample bocor. Pada percobaan tekanan bar 6 diperoleh hasil 8 dari 30 sampel finish good bocor atau sebanyak $27 \%$ dari sampel bocor
Tabel 3. Tabel Validasi Tekanan Bar Mesin Auto Capper

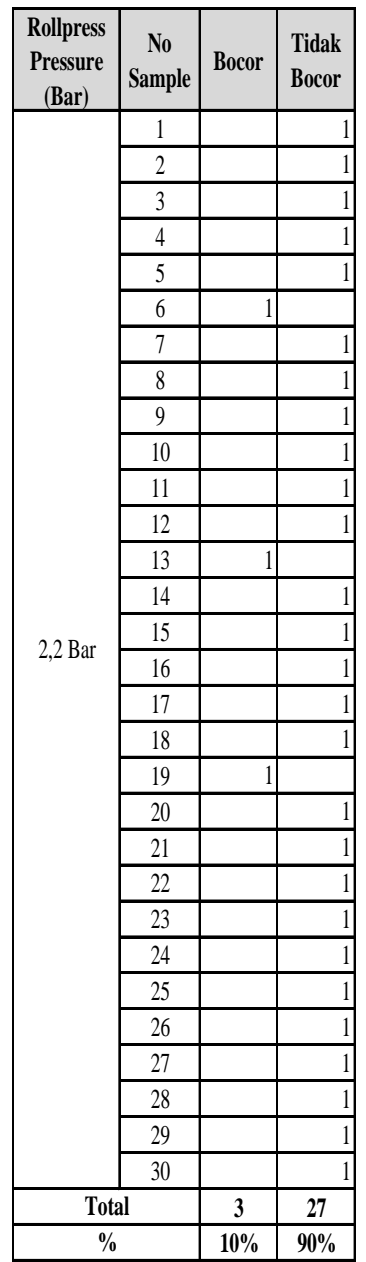

\begin{tabular}{|c|c|c|c|}
\hline $\begin{array}{c}\text { Rollpress } \\
\text { Pressure } \\
\text { (Bar) }\end{array}$ & $\begin{array}{c}\text { No } \\
\text { Sample }\end{array}$ & Bocor & $\begin{array}{l}\text { Tidak } \\
\text { Bocor }\end{array}$ \\
\hline \multirow{30}{*}{3 Bar } & 1 & & 1 \\
\hline & 2 & & 1 \\
\hline & 3 & & 1 \\
\hline & 4 & & 1 \\
\hline & 5 & & 1 \\
\hline & 6 & & 1 \\
\hline & 7 & & 1 \\
\hline & 8 & & 1 \\
\hline & 9 & & 1 \\
\hline & 10 & 1 & \\
\hline & 11 & & 1 \\
\hline & 12 & & 1 \\
\hline & 13 & & 1 \\
\hline & 14 & & 1 \\
\hline & 15 & & 1 \\
\hline & 16 & & 1 \\
\hline & 17 & & 1 \\
\hline & 18 & & 1 \\
\hline & 19 & & 1 \\
\hline & 20 & & 1 \\
\hline & 21 & & 1 \\
\hline & 22 & & 1 \\
\hline & 23 & & 1 \\
\hline & 24 & & 1 \\
\hline & 25 & & 1 \\
\hline & 26 & & 1 \\
\hline & 27 & & 1 \\
\hline & 28 & & 1 \\
\hline & 29 & & 1 \\
\hline & 30 & & 1 \\
\hline \multicolumn{2}{|c|}{ Total } & 1 & 29 \\
\hline \multicolumn{2}{|c|}{$\%$} & $3 \%$ & $97 \%$ \\
\hline
\end{tabular}
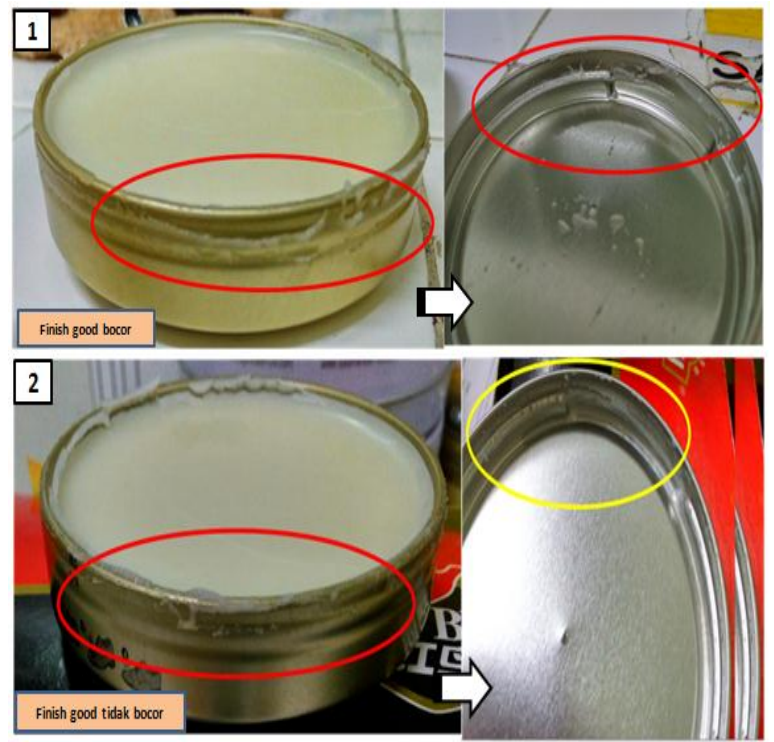

Gambar 8. Finish Good Hasil Validasi Tekanan Bar 
Jika dilihat pada gambar 8 bagian 1 terlihat bagian pasta yang mencair keluar dari area tutup dan body kemasan pasta,hal tersebut yang terjadi pada tekanan bar : 2.2 bar, 3 bar, 4 bar, dan 6 bar. Dan pada gambar 2 bagian 2 terlihat bagian pasta yang mencair tidak keluar dari area tutup dan body kemasan pasta hal tersebut yang terjadi pada tekanan 5 bar. Berdasarkan hasil validasi di atas jumlah bar yang dipakai adalah pada tekanan 5 bar dikarenakan berasarkan data didapatkan hasil $0 \%$ bocor.

Implementasi perbaikan yang dilakukan pada faktor metode adalah dengan thermometer dan memasang forr reford temperature pada area dry produksi dan area warehouse. Hal ini bertujuan agar bisa diketahui secara detail data kuantitatif dari temperature area tersebut (gambar 9)..

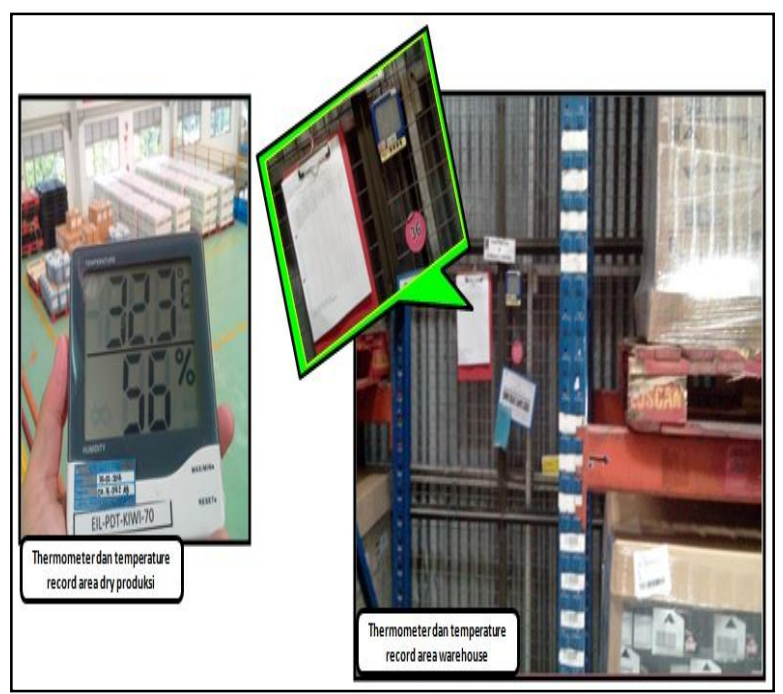

Gambar 9. Pemasangan thermometer pada area warehouse

Implementasi perbaikan yang dilakukan pada faktor environment adalah dengan mencari penyebab yaitu suhu temperatur area ruang penyimpangan di atas standar, dikarenakan kondisi overload kapasitas produksi, sehingga produk disimpan di lokasi yang bukan seharusnya. Implementasi yang dilakukan adalah dengan melakukan order PO costumer dengan menyesuaikan dari kapasitas produksi

Implementasi perbaikan yang dilakukan pada faktor manusia adalah dengan melakukan briefing terkait pada operator yang bertugas di line tersebut. selain dilakukan penerapan sistem LOTO (Lockout Takeout) yaitu membuat suatu box terkunci untuk alat setting bar dan kunci tersebut dipegang oleh engineering yang bertugas (gambar 10).
Gambar 4. Contoh Form Temperature Record Area Produksi Dan Warehouse

\section{LFBEAUTY.}

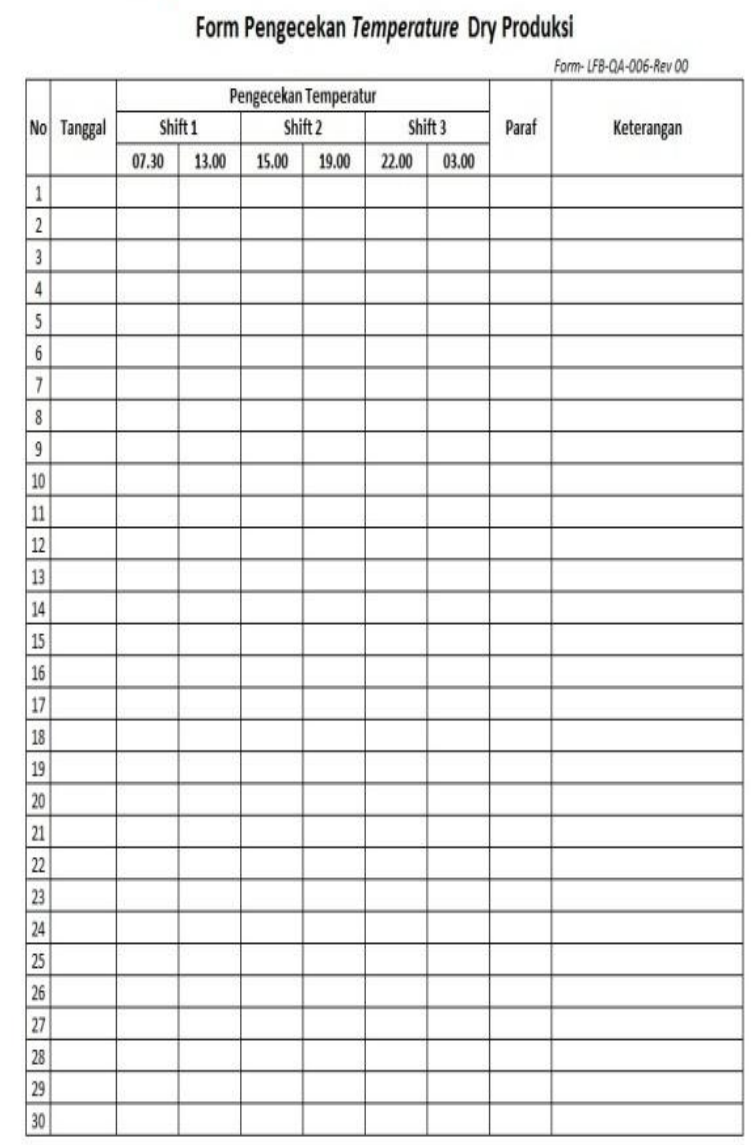

\section{LFBEAUTY.}

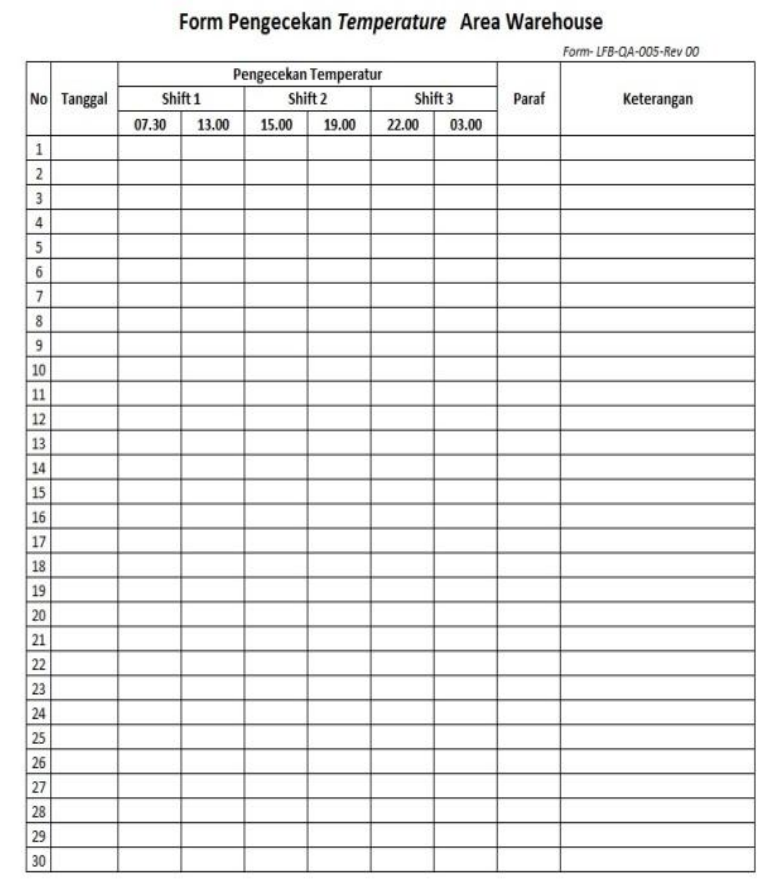




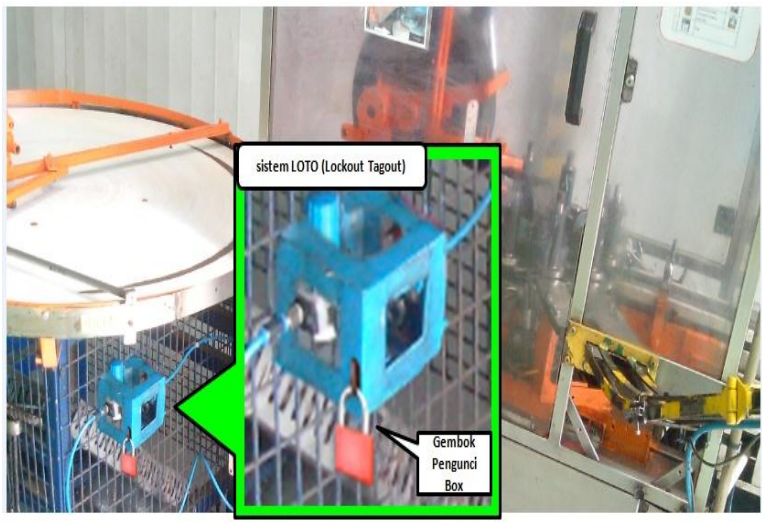

Gambar 10. Sistem LOTO (Lockout Tagout)

\section{Control}

Pada tahap ini dilakukan pengukuran dan pengendalian terhadap kegiatan usulan perbaikan dan implementasi yang telah dilakukan pada line Kiwi Pasta PT. LF Beauty Manufacturing Indoneia. Pada tahap control ini akan diketahui apakah tindakan perbaikan yang telah dilakukan dapat memberikan peningkatan kualitas pada produk atau tidak. Pada tahap control ini yang dibaca adalah defect tersebut tidak akan timbul lagi dengan complaint yang sama dikemudian hari. Pada akhirnya dapat menghilangkan defect tersebut. Setelah dilakukan perbaikan selama 6 bulan, diperoleh peningkatan nilai sigma dari 4,200 menjadi 5,280 , berdasarkan keluhan pelanggan PT JHHP pada bulan Juli 2016 .

Tabel 5. Data Keluhan Cacat Setelah Implementasi

\begin{tabular}{ccccc}
\hline $\begin{array}{c}\text { Tanggal } \\
\text { Keluhan }\end{array}$ & Produk & $\begin{array}{c}\text { Tanggal } \\
\text { Produksi }\end{array}$ & $\begin{array}{c}\text { Jumlah } \\
\text { Temuan }\end{array}$ & $\begin{array}{c}\text { Jumlah } \\
\text { Produksi }\end{array}$ \\
\hline Kiwi Wax Rich & & & \\
20 Juli & $\begin{array}{c}\text { Shine \& Prict } \\
\text { Brown }\end{array}$ & $\begin{array}{c}15 \text { Maret } \\
\text { 2016 }\end{array}$ & 12 & 5200 \\
& $75 G / 24652156$ & & & \\
& & & & \\
\end{tabular}

Pengukuran Sigma Quality Level digunakan sebagai pembanding (benchmark) terhadap proses terbaik dan juga sebagai data terukur untuk menetapkan target perbaikan selanjutnya. Dengan adanya ukuran / metrik yang telah diketahui, maka kita akan dapat melihat besarnya progress yang dicapai setelah dilakukan improvement dan hasilnya apakah telah sesuai dengan target atau tidak.
Dengan dilakukan benchmarking dapat diketahui bahwa kemampuan proses Kiwi Paste yang dicapai pada saat ini berdasarkan sigma quality level masih menempati kualitas perusahaan dengan Good Company Average namun terdapat perbaikan dipenurunan angka DPMO dari 3.497 ppm menjadi 568 ppm (gambar 11).

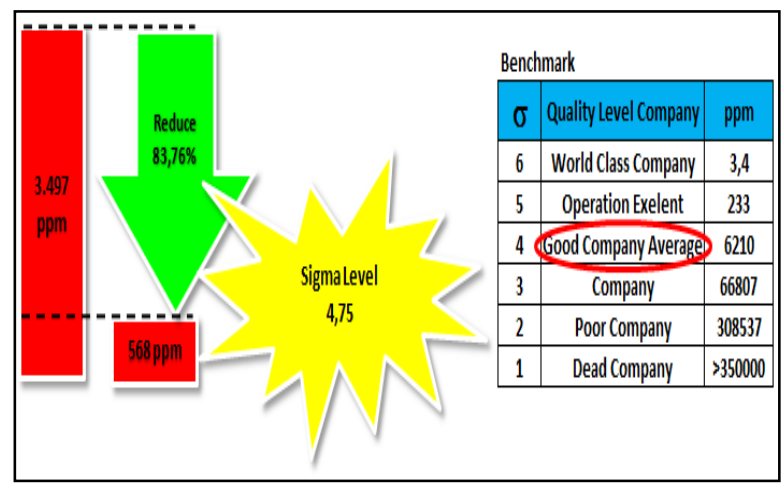

Gambar 11. Monitoring Defect Complain Setelah Perbaikan

\section{KESIMPULAN}

Dari data dan hasil analisis yang telah dilakukan, maka dapat ditarik kesimpulan bahwa cacat terbesar produk kiwi paste yang sesuai dengan diagram adalah finish good bocor. Faktor - faktor yang mempengaruhi keluhan cacat finish good bocor produk kiwi paste adalah operator sering melakukan adjusment angin mesin autocapper, belum tersedianya alat termometer ruang pada area warehouse dan area dry produksi, belum tersedianya alat ukur tekanan angin yang dipakai untuk mengetahui jumlah bar yang dipakai dalam proses assemble dan temperatur ruang area penyimpanan melebihi dari standar yang ditetapkan. Nilai defect mengalami penurunan, sebelum implementasi 3.497 DPMO dengan level sigma 4,20 $\sigma$ menjadi 568 DPMO dengan level sigma 4,75 $\sigma$. Penelitian ini dapat dilanjutkan dengan menerapkan metode Lean Six Sigma untuk mendapatkan hasil yang lebih baik lagi.

\section{DAFTAR PUSTAKA}

[1] A. Cherrafi, S. Elfezazi, A. Chiarini, A. Mokhlis, and K. Benhida, "The integration of lean manufacturing, Six Sigma and sustainability: A literature review and future research directions for developing a specific model," J. Clean. Prod., vol. 139, pp. 828-846, 2016. 
[2] R. G. Schroeder, K. Linderman, C. Liedtke, and A. S. Choo, "Six Sigma: Definition and underlying theory," J. Oper. Manag., vol. 26, no. 4, pp. 536-554, 2008.

[3] F.-K. Wang and K.-S. Chen, "Applying Lean Six Sigma and TRIZ methodology in banking services," Total Qual. Manag., vol. 21, no. 3, pp. 301-315, 2010.

[4] A. G. Psychogios, J. Atanasovski, and L. K. Tsironis, "Lean Six Sigma in a service context: a multi-factor application approach in the telecommunications industry," Int. J. Qual. Reliab. Manag., vol. 29, no. 1, pp. 122-139, 2012.

[5] H.-C. Hung and M.-H. Sung, "Applying six sigma to manufacturing processes in the food industry to reduce quality cost," Sci. Res. Essays, vol. 6, no. 3, pp. 580-591, 2011.

[6] S. Supriyadi, G. Ramayanti, and A. Chandra Roberto, "Analisis Kualitas Produk dengan Pendekatan Six Sigma," in Prosiding SNTI dan SATELIT, 2017, pp. 7-13.

[7] B. Bergman and B. Klefsjö, Quality from customer needs to customer satisfaction. Lund, Sweden: Studentlitteratur AB, 2010.

[8] P. Jirasukprasert, J. Arturo Garza-Reyes, V. Kumar, and M. K. Lim, "A Six Sigma and DMAIC application for the reduction of defects in a rubber gloves manufacturing process," Int. J. Lean Six Sigma, vol. 5, no. 1, pp. 2-21, 2014.

[9] P. Abreu, S. Sousa, and I. da S. Lopes, "Using Six Sigma to improve complaints handling," in World Congress on Engineering 2012 (WCE 2012), 2012, pp. 1363-1368.

[10] N. Fadly Habidin and S. Mohd Yusof, "Critical success factors of Lean Six Sigma for the Malaysian automotive industry," Int. J. Lean Six Sigma, vol. 4, no. 1, pp. 60-82, 2013.

[11] J. Antony, F. Jiju Antony, M. Kumar, and B. Rae Cho, "Six sigma in service organisations: Benefits, challenges and difficulties, common myths, empirical observations and success factors," Int. J. Qual. Reliab. Manag., vol. 24, no. 3, pp. 294-311, 2007.

[12] M. Kumar, J. Antony, F. J. Antony, and C. N. Madu, "Winning customer loyalty in an automotive company through Six Sigma: a case study," Qual. Reliab. Eng. Int., vol. 23, no. 7, pp. 849-866, 2007.

[13] H. P. Rakasiwi and H. Haryono, "Analisis Six Sigma Pada Produk Casing Pompa
Sebagai Metode Perbaikan Kualitas (Studi Kasus: PT. Zenith Allmart Precisindo)," J. Sains dan Seni ITS, vol. 3, no. 2, pp. D67-D72, 2014.

[14] S. Supriyadi, G. Ramayanti, and Y. Aditia, "Analisa Kualitas Precious Slag Ball dengan Pendekatan Six Sigma," in Proceedings Seminar IImiah Nasional, 2017, pp. 45-58.

[15] T. C. Hendradi, "Statistik six sigma dengan Minitab," Pandu. Cerdas Inisiat. Kualitas. Yogyakarta ANDI OFFSET, 2012. 